\title{
A Decade of a Maturing Epidemic: An Assessment and Directions for Future Public Policy
}

Lawrence O. Gostin

Georgetown University Law Center, gostin@law.georgetown.edu

This paper can be downloaded free of charge from:

https://scholarship.law.georgetown.edu/facpub/765

5 Notre Dame J.L. Ethics \& Pub. Pol'y 7-33 (1990)

This open-access article is brought to you by the Georgetown Law Library. Posted with permission of the author. Follow this and additional works at: https://scholarship.law.georgetown.edu/facpub

Part of the Health Law and Policy Commons, Health Policy Commons, Public Health Commons, and the Public Policy Commons 


\title{
ARTICLES
}

\section{A DECADE OF A MATURING EPIDEMIC: AN ASSESSMENT AND DIRECTIONS FOR FUTURE PUBLIC POLICY $†$}

\author{
LARry Gostin*
}

Since AIDS was first identified in 1981, its rate of spread among a primarily young and vibrant population has chilled the medical and lay communities. Today, the public response is sober and oriented toward the examination of specific policies that could lessen the impact of the disease. After nearly a decade of experience, it is now feasible (many would say long overdue) to implement a comprehensive strategy for combatting AIDS. Consensus around the policies put forward in this essay should form the nucleus of the public health strategy to confront AIDS before the intervention of an effective vaccine or curative treatment.

The policies reviewed in this essay are not new. Indeed most of them are now well accepted public health priorities, endorsed by the Presidential Commission on the HIV epidemic $^{1}$ and the National Commission on Acquired Immune Deficiency Syndrome. ${ }^{2}$ What is remarkable is that effective policies, uniformly recommended by public health officials, have not been implemented by government. Admiral Watkins,

$\dagger$ This paper first appeared as the preface to the Harvard Model AIDS Legislation Project Symposium in 16 AM. J. L. \& MED. 1 (1990).

* Executive Director, American Society of Law \& Medicine; Adjunct Associate Professor of Health Law, Harvard School of Public Health, Lecturer on Law, Harvard Law School. The author is editor of a new book from Yale University Press entitled AIDS and the Health Care System (1990).

1. Report of the Presidential Commission on the Human Immunodeficiency Virus Epidemic (June 24, 1988) [Hereinafter cited as Presidential Commission]. See also Institute of Medicine/National Academy of Sciences, Confronting AIDS: Directions for Public Health, Health Care and Research (1986) [Hereinafter cited as Confronting AIDS], and Confronting AIDS: Update 1988 (1988) [Hereinafter cited as Update 1988].

2. See letter by David Rogers (Vice Chair) and June Osborne (Chair), to President Bush (Dec. 5, 1989). 
Chairman of the Presidential Commission has criticized "inconsistent federal leadership," stating that the "institutional responses of the federal government have been unsuccessful in facilitating the response to the public health emergency." 3 The Institute of Medicine similarly criticized the "lack of cohesiveness and strategic planning," "the lack of guidance in federal policy-making is manifested by false starts and misguided efforts; some illustrations include interdepartmental disputes over the proper educational approach, the administration's advocacy of screening for certain low risk populations, and the failure to move rapidly to reduce the risk of HIV transmission among IV drug users.",

Former President Reagan did not utter the word "AIDS" until well into his second term in office; the executive branch until quite recently spent only a fraction of the AIDS appropriations allocated by Congress; and the President explicitly accepted only a few of the hundreds of recommendations made in the Presidential Commission report. ${ }^{5}$ October 1988 was "National AIDS Awareness and Prevention Month." Yet, the administration waited until November 1,1988 to issue a proclamation calling on all Americans to observe the occasion "with appropriate ceremonies and activities."

The new National Commission on AIDS continues to express concern that its voice is not heard by President Bush. In its first report, the Commission observed that "there is no national policy or plan, no national voice . . . without federal leadership the states have assumed the responsibility. ${ }^{6}$ More recently, the National Commission in a report to President Bush said that AIDS Policy in the U.S. is like, "an orchestra without a conductor" because the government has failed to effectively lead a campaign against the epidemic, "all across the country there is a cry for leadership from the federal government ..." The Commission recommended that the administration establish a cabinet group to set up a coordinated national plan on the HIV epidemic. ${ }^{7}$

3. This portion of Admiral Watkins' report was not accepted by the full Commission.

4. Update 1988 , supra note 1 .

5. Implementing Recommendations of the Presidential Commission on the Human Immunodeficiency Virus Epidemic: The 10-Point Plan (Aug. 2. 1988). 1989)

6. National Commission on AIDS, Report Number One 6 (Dec. 5,

7. Hilts, Panel Says Government is Not Leading AIDS Fight, N.Y. Times, Apr. 25, 1990, at Al. 
My goal, then, is not merely to propose public health strategies for the future, but also to examine why government has been so slow, so equivocal, in its public health response to the epidemic. I argue that there has been a fundamental ambivalence in perceptions of the epidemic. For some, AIDS is perceived as a disease, with sympathy for sufferers. Once AIDS is viewed as a disease, like other catastrophic diseases, it follows that public policy will be based upon science and epidemiology - health education, research and treatment.

For others, AIDS is caused by willful, irresponsible behavior. Persons infected with HIV are seen as morally blameworthy and deserving of punishment. Once AIDS is seen to be caused by willful, immoral behavior, public policy will, at least in part, be punitive towards persons carrying the infection (e.g., criminal penalties and discriminatory treatment), and overly protective of the sensibilities and morals of the wider community (e.g. , censorship of explicit public health messages directed at those groups who are blamed for spread of the epidemic).

This ambivalence in perception of this epidemic has manifested itself on two levels, both of which are critically important for understanding the policies and politics of AIDS. There is a substantial minority of public opinion which consistently shows a callous hostility towards persons with AIDS. ${ }^{8}$ Thus, virtually any draconian position for AIDS patients receives some public support: patients are "offenders getting their rightful due"; "they should be tattooed"; they should be dealt with as "lepers" and sent off to far-off islands. A similar proportion of the public would not work alongside AIDS patients or would exclude infected children from schools, neighborhoods and public housing. A certain percentage of the public even believes that persons with AIDS should not be treated compassionately, perhaps the clearest possible indication of hostility. ${ }^{9}$

This hostile minority of public opinion has found expression in law and public policy. Statutes have been enacted at a federal and state level which restrict the dissemination of educational messages because of their morally offensive content. ${ }^{10}$

8. Blendon \& Donelan, Discrimination Against People with AIDS, $319 \mathrm{~N}$. EnG. J. Med. 1022 (1988); Singer, Rogers \& Corcoran, The Polls $-A$ Report: $A I D S, 51$ Pub. Opinion Q. 580 (1987).

9. Id.

10. See, e.g., H.J. Res. 395, Continuing Resolution for FY 88 appropriations (federal "Helms" Amendment) as modified by the federal Health Omnibus Programs Extension Act of 1988 (forbids funding AIDS prevention programs that "promote or encourage, directly homosexual or heterosexual activity or intravenous drug use"). 
Other statutes seek to control the person with HIV through compulsory testing, isolation or criminalization, despite the absence of public health support for such coercive measures. ${ }^{11}$

There have been well over fifty criminal prosecutions brought against persons infected with HIV for spitting, biting, splattering blood, donating blood, and having sexual relations. New statutes have also been enacted which provide for draconian criminal penalties for behaviors which risk the transmission of HIV. ${ }^{12}$ The striking aspect of these prosecutions is that in no criminal case to date has HIV actually been transmitted. Persons with HIV are being prosecuted for risks which are remote or negligible.

Biting, splattering or even donating HIV contaminated blood is certainly irresponsible, indeed callous, behavior. But the risk of transmitting the virus approaches zero. ${ }^{13}$ In comparison, the hepatitis B virus is much more easily transmissible. ${ }^{14}$ It also causes many more deaths than HIV from parenteral or mucous membrane exposure of the kind that could occur with non-sexual aggressive behavior. ${ }^{15}$ Yet, there has never been a reported case of a serious criminal prosecution for risking transmission of $\mathrm{HBV}$.

It is understandable for society to draw a bright line around truly dangerous behavior it will not tolerate such as repeated sexual intercourse when the person knows he is infected with HIV. However, society seems prepared to deprive HIV-infected persons of their liberty, under the mantle of public health, for taking remote risks. The exercise of compulsory powers is often based upon unproven fears, perhaps prejudice, and not upon a rational assessment of scientific facts.

11. See generally Gostin, The Politics of AIDS: Compulsory State Powers, Public Health and Civil Liberties, 49 Oнго ST. L.J. 1017 (1989); Sullivan \& Field, AIDS and the Coercive Power of the State, 23 Harv. C.R.-C.L.L. REv. 139 (1988).

12. Id.

13. See Gostin, supra note 10, at 1020-26; Friedland \& Klein, Transmission of the Human Immunodeficiency Virus, 317 N. ENG. J. MED. 1125 (1987).

14. There is a range of 0.03 to 0.9 percent probability that a person will contract HIV following a documented case of percutaneous exposure to HIV. infected blood. Friedland \& Klein, supra note 13. This rate of seroconversion compares favorably with the risk of $12.17 \%$ after percutaneous injection with HBV contaminated blood. Centers for Disease Control Update: Human Immunodeficiency Virus in Health Care Workers Exposed to Blood of Infected Patients, 36 Morbidity \& Mortality WkLy Rep. 285 (1987).

15. The Centers for Disease Control estimates that 500-600 health care professionals whose jobs entail exposure to blood are hospitalized annually with HBV infections, and over 200 of those hospitalized die from the virus. 52 Fed. Reg. 41,818 (1987). 
Public opinion and public policy, then, pull in two opposite directions - public health and sympathy for the AIDS patient on the one hand, and coercion and moral indignation on the other. This results in a confusing, contradictory educational message, and disjointed, fragmented public policy. It is not surprising that the Presidential Commission, National Commission, and the Institute of Medicine AIDS panels sharply criticized government planning and leadership through nearly a decade of a maturing epidemic.

Below, I set out a number of constructive public health policies which have gained virtually unanimous support in the public health community. These should be the priorities for our public health agenda for the decade, and not the largely irrelevant moral and punitive concerns which have captured a large segment of media reports, public opinion and legislative initiative.

\section{Prevention: A Comprehensive and Well-Resourced Program of Education}

There has been great hope and expectation - much of it false - that the AIDS epidemic might be eradicated by the "magic bullet" of technology. But the chances of an early breakthrough in vaccine development (like the Salk vaccine in the Polio epidemic) have faded. ${ }^{16}$ Others hope that simply willing the epidemic away by moral directives to "say no" or harsh criminal penalties for transmission would work. The fact is that neither science, law nor ethics hold out much prospect for confronting AIDS in the near future.

But we do know a great deal about how HIV is transmitted and about the behavioral changes necessary to slow the epidemic. Epidemiological research has revealed more about HIV in a relatively short period than about any other human retrovirus. This information can be used with great effect to combat the spread of HIV. Studies demonstrate rapid, profound, but expectably incomplete, alterations in behavior among gays and IV drug users exposed to comprehensive health education programs. ${ }^{17}$ In some urban gay communities such as in San Francisco and New York, the reduction in high

16. See Mariner, Why Clinical Trails of AIDS Vaccines Are Premature, 79 AM. J. Pub. Health 86 (1989); Gostin, Vaccination for AIDS: Legal and Ethical Challenges from the Test Tube, to the Human Subject, Through to the Marketplace, 2 AIDS \& Pub. Pol'y J. 9 (1987).

17. See Becker \& Joseph, AIDS and Behavioral Change to Reduce Risk: A Review, 78 Aм. J. Pub. Health 1472 (1988). 
risk behaviors has been spectacular with the rate of new infections declining by $88 \%$ over nine months to under $1 \%$ of the population. ${ }^{18}$ Thus, even sexual behaviors which are biologically driven and IV drug use which is physically addicting can be significantly altered.

The first line of defense in controlling AIDS, therefore, is to inform and educate individuals about high risk behavior and about methods for altering behavior to protect against transmission of infection.

The overarching importance of prevention and education has been frequently stated by public health authorities. ${ }^{19}$ The Congress and many states have mandated AIDS education which focuses on four populations: ${ }^{20}$

(i) The General Public - Legislatures have sponsored AIDS education campaigns (including non-English campaigns). These include sending letters to every household, designating "AIDS Awareness" months and establishing an "AIDS hotline." Some legislation emphasizes specific areas of education such as the safety of donating blood or encouraging testing.

(ii) High Risk Groups - Some states authorize the distribution of graphic homosexual literature, teaching the use of condoms and sterilization of drug paraphernalia, and outreach programs for drug dependent populations.

(iii) Health Care Professionals - Educational programs are required for all health care workers in several states. Physicians, dentists and emergency workers are required to receive training in blood and body fluid precautions. Florida has enacted a highly comprehensive package requiring mandatory training for health care workers, law enforcement officers, teachers and state employees. Failure of a physician to comply will result in revocation of a medical license.

(iv) Schools - AIDS education is required in several states at a primary, secondary or even college level. Other states require training of teachers and employees.

Public health officials and legislators, of course, can frustrate as well as facilitate educational objectives. Some officials at federal and state levels have been decidedly squeamish about

18. Winkelstein, Wiley, Padian, et al, The San Francisco Mens Health Study: Continued Decline in HIV Seroconversion Rates Among Homosexual/Bisexual Men, 78 Am. J. Pub. Health 1472 (1988).

19. See, e.g., Update 1988, supra note 1, at 64-68; Fineberg, Education to Prevent AIDS: Prospects and Obstacles, 239 Science 592 (1988); Cleary, Education and Prevention of AIDS, 16 Law Med. \& Health Care 267 (1988).

20. See Gostin, Public Health Strategies for Confronting AIDS: Legislative and Regulatory Policy in the United States, 261 J. A.M.A. (1989). 
explicit sex education. Religious and moral beliefs have interfered with critical efforts to disseminate accurate and clear public health information. The U.S. Centers for Disease Control has said that education of the gay and IV drug communities would have to be "judged by a reasonable person to be unoffensive to most educated adults beyond those groups." Yet, it is impossible to provide clear, explicit information to gays, IV drug users, prostitutes and others about "safer" behaviors without offending some members of the general public.

Several major cities have prevaricated about explicit sex education, with New York City at one point censoring an educational film for public schools. Boston disapproved an AIDS educational leaflet directed to the gay community because of its graphic images and language.

The Public Health Service under DHHS regulation has until recently been prevented from using paid advertising on television. ${ }^{21}$ Further, the major networks and a large part of the written and electronic media do not accept advertisements about the use of condoms. ${ }^{22}$ The United States media is far behind other countries in Europe, the Americas and the Commonwealth in frank media discussion of safer sexual and drug using behaviors. ${ }^{23}$

The public's ambivalence toward AIDS education was manifested in the federal "Helms" Amendment to the HHS appropriations bill ${ }^{24}$ passed by overwhelming majorities in the House and Senate. The Amendment prohibits the use of federal funds for educational materials "that promote or encourage, directly or indirectly, homosexual activities." The Health Omnibus Programs Extension Act of $1988^{25}$ appeared both to limit and to widen the scope of the Helms Amendment. The 1988 Act prohibits education "designed to promote or encourage, directly, homosexual or heterosexual activity or intravenous substance abuse." Almost paradoxically, the Act goes on to say that this limitation should not be construed to restrict the ability of an education program to provide accurate information, provided that the informational materials are not obscene.

The approach of the Helms Amendment has been adopted in seven states that require schools to stress abstinence, "until

21. Update 1988 , supra note 1 , at 65 .

22. Id. at 69 .

23. See W.J. Curran \& L. Gostin, International Survey of Legislation Relating to the AIDS Epidemic (WHO, Geneva 1988).

24. Pub. L. No. 100-202, Title 5, § 514, 1988.

25. Pub. L. No. 100-607. 
one is ready to form an exclusive relationship within the institution of marriage." 26

Educational restrictions impede the ability of public officials to disseminate effective AIDS prevention materials. "Efforts to stifle candid materials that discuss safer sexual practices and that are targeted at appropriate audiences may take a toll in human lives." 27

The former Surgeon General, C. Everett Koop, called for this "silence to end," to give way to frank, open discussions about sexual practices - homosexual and heterosexual. Sex education materials must be graphic and appropriate to the target audience. Accordingly, such materials should be clear in warning that fellatio and unprotected vaginal and anal sex with an infected person poses a real probability of transmission of the virus. Information given to drug-dependent people must also be frank in describing the risk of transmission from sharing contaminated needles.

Public health departments must be realistic in understanding that behaviors of an intimate or addicting nature are difficult to alter. Many young men and women will not abstain from sex, prostitution, or drug abuse. They need unambiguous instruction about how to engage in gay or heterosexual relations in a reasonably safe manner. Drug-dependent people require clear information about the use of sterile needles, where they can be obtained or, minimally, how they can be sterilized. Thus, the information must be explicit, understandable, and directly relevant to the target audience. Public health officials cannot overly concern themselves with morality or even the fact that the behavior is unlawful. The ultimate concern is to secure changes in behavior conducive to the health of the people.

\section{A Widespread Program of Voluntary Testing AND Counseling}

Routine testing of persons at high risk for HIV infection has long been recommended by the U.S. Centers for Disease Control. ${ }^{28}$ The CDC recommends pre- and post-test counsel-

26. Gostin, supra note 16.

27. Update 1988, supra note 1, at 66. See Booth, Another Muzzle for AIDS Education?, 238 SCIENCE 1036 (1987).

28. Centers for Disease Control, Additional Recommendations to Reduce Sexual and Drug Abuse-Related Transmission of Human TLymphotropic Virus Type III/Lymphadenopathy-Associated Virus, 35 MORBIDITY \& MORTALITY WKLY. REP. 152 (1986). 
ing as an essential part of any testing program. ${ }^{29}$ The objectives of testing and counseling are to modify behavior and to cope with the psychological burdens of contracting a potentially lethal infection.

One of the foundations for voluntary modification of behavior is knowledge about serological status. Individuals can often make the best decisions about their health and the protection of others if they are tested for HIV antibodies. Knowledge of seropositivity can allow a person to take precautions against transmitting the virus.

An HIV positive test result can have a devastating psychological impact on the individual, including a significant risk of suicide. $^{30}$ Counseling is necessary to assist and support individuals in coping with the psychological burdens and to adapt their behaviors.

Testing and counseling should be widely available to persons who engage in higher risk behaviors. Many states have "alternative test sites" that provide testing for the AIDS virus. These sites, however, often do not provide adequate counseling services, have long waiting times, inconvenient locations, and uncertain confidentiality protections. There has, moreover, been no development of a strategic plan or allocation of adequate resources to provide testing and counseling for all those who could use these services as a basis for changes in behavior.

Voluntary testing and counseling, then, are potentially valuable public health programs to encourage reductions in high risk behaviors. However, to some, HIV screening (whether or not associated with counseling) is seen as a panacea, which should be used quite broadly, even compulsorily. Gary Bauer, Policy Assistant to former President Reagan, has called AIDS a "politically protected epidemic" requiring "routine testing in most cases, and mandatory testing in some as proposed by President Reagan."31 "Routine" screening is seldom carefully defined, but appears to involve wide-scale testing without requiring a specific informed consent in each case.

Mandatory screening programs may seem intuitively obvious, because no public health strategy can be effective unless

29. Centers for Disease Control, Public Health Service Guidelines for Counseling and Antibody Testing to Prevent HIV Infection and AIDS, 36 Morbidity \& MORTality W KLY. ReP. 509 (1987).

30. Marzuk, Tierney, Tardiff, Gross, Morgan, Hsu, Mann, Increased Risk of Suicide in Persons with AIDS, 259 J. A.M.A. 1333 (1988); Glass, AIDS and Suicide, 259 J. A.M.A. 1369 (1988).

31. Bauer, AIDS Testing, 2 AIDS ANd PUB. PoL'y J. 1 (1987). 
cases of HIV can be identified. Casefinding, it is argued, is the first line of defense in curbing the epidemic. While compulsory screening may seem obvious, if examined logically it can be seen as ineffective and possibly counterproductive. There are several possible justifications for compulsory screening which I will review in turn. ${ }^{32}$

First, a person can be expected to make more rational decisions about behavior change if he is informed about his serological status. This is an assumption that has yet to be demonstrated. There is still insufficient behavioral research to prove whether knowledge of seropositivity influences behavior and in what direction. The appropriate precautions in personal conduct to reduce the spread of HIV are already well-known to most members of high-risk groups. ${ }^{33}$ Knowledge of seropositivity may be helpful to some in modifying their behavior. However, to others education and counseling will be the critical factor, regardless of test results.

Even if it could be demonstrated that knowledge of a positive test result does significantly influence behavior, it does not necessarily follow that compelling a person to take an antibody test will produce voluntary changes in behavior. The spread of HIV can be reduced only through the willingness of individuals to avoid unsafe sexual and needle-sharing behavior. Introduction of compulsory screening may have the reverse effect of causing persons vulnerable to HIV to avoid coming forward for testing, counseling, and treatment. If the public health strategy is to encourage as many people as possible to receive education and counseling, then the use of measures that can be regarded as controlling or punitive might be counterproductive.

A second argument in support of mandatory screening is that it provides an early indicator of disease status so that the person can come in for prompt treatment. Knowledge of seropositivity cannot be used to alleviate an infectious condition, since there is currently no vaccine for prevention or established treatment of HIV infection. HIV is unlike venereal disease, where the chain of infection can be broken by simple antibiotic

32. See Field, Testing for AIDS: Uses and Abuses, 16 AM. J. L. \& MEd. 33 (1990); Gostin, Curran \& Clark, The Case Against Compulsory Casefinding in Controlling AIDS: Testing, Screening and Reporting, 12 AM. J. L. \& MED. 7 (1987); Gostin, Screening for AIDS: Efficacy, Cost, and Consequences, 2 AIDS \& PUB. PoL'y J. 14 (1987).

33. See Becker \& Joseph, supra note 17. 
treatment. ${ }^{34}$ Thus, even with early knowledge of a person's serological status, medicine cannot alter the cycle of infection.

Although knowledge of seropositivity enables a person to seek early treatment with such developing therapies as azidothymidine (AZT), and studies suggest that asymptomatic people with reduced T4 cell counts might also benefit. ${ }^{35}$ It is difficult to sustain an argument for compulsory screening of large populations in the hope that some might have access to a treatment sooner than they would otherwise by visiting their physician at the first sign of a clinical problem.

It is, of course, possible to suggest that persons who know they are seropositive can concentrate on a good diet, exercise, and stress avoidance in the hopes of bolstering their immune systems. But this is a uniquely individual decision. It makes little sense to compel an individual to take a test for his own health, for a positive test result may cause greater stress and psychological harm. In any case, compelling a patient to receive a test or treatment without informed consent is contrary to legal and ethical norms in the practice of medicine. ${ }^{36}$

A third argument in support of mandatory screening is that it will assist public health officials in gaining a truer epidemiologic picture of the spread of HIV. Current epidemiologic surveillance is substantially based on the reporting of CDCdefined AIDS. Since it may take five years or more for a person to develop the disease from the time of infection, we do not have an accurate, current assessment of the amount of infection in the United States. ${ }^{37}$

Mandatory screening programs would not necessarily accomplish this epidemiologic objective, because many states still only require reporting of the disease and not a positive test result. ${ }^{38}$ Even if states did introduce reporting requirements for infection (as many are), there are other more effective, less restrictive methods of obtaining a better epidemiologic understanding of infection patterns across the United States. Many

34. See A. Brandt, No Magic Bullet: A Social History of Venereal Disease in the United States Since 1880 (1987).

35. Volberding, Lagakos, Koch et al, Zidovudine in Asymptomatic Human Immunodeficiency Virus Infection, 322 N. ENG. J. MED. 941 (1990); Friedland, Early Treatment for HIV, 322 N. ENG. J. MEd. 1000 (1990).

36. Brandt, Cleary \& Gostin, Routine Hospital Testing for HIV, in AIDS and the Health Care System 125 (L. Gostin ed. 1990).

37. Mueller, The Epidemiology of the Human Immunodeficiency Virus Infection, 14 Law, Med. \& Health Care 250 (1986).

38. Centers for Disease Control, HIV Infection Reporting, 38 Morbidity \& Mortality WKLy. ReP. 496 (1989). 
states have begun blind epidemiologic research. This involves testing samples of blood collected for other purposes (e.g., in hospitals or maternity clinics). The samples are not identified by name, but only by demographic characteristics. Using scientific sampling theory is much more likely to produce an accurate epidemiologic understanding than ad hoc testing and reporting requirements. Thus, an important epidemiologic purpose is served without any mandatory intervention or chance that positive results will be disclosed to third parties.

The public health benefit of mandatory screening, therefore, is likely to be marginal or counterproductive for three reasons: (1) there is no evidence that the use of compulsion would lead to voluntary changes in behavior; (2) no curative treatment or prevention for AIDS exists; and (3) epidemiologic information can be gathered in a less intrusive manner by blind research. Balanced against this marginal public health benefit is the potential for substantial harm to those screened. Each person screened, whether seropositive or not, must submit involuntarily to the taking to a blood sample and the collection of sensitive health care information.

Moreover, collection of information creates a demand for its use. Unauthorized disclosure of that information could result in opprobrium among family and friends and discrimination in employment, housing, and insurance. The adverse consequences of screening are serious enough for true positives, even though the great majority are likely to be asymptomatic. In addition, there will be a number of individuals who test positive in the ELISA and supplementary tests, but who do not harbor the virus. The price of screening includes the potential for stigma and discrimination to the false-positive population.

Widespread screening has public resource, as well as personal implications. Screening requires the administration and interpretation of the ELISA together with supplementary procedures. This entails significant expense for the administration of laboratories, test equipment, and personnel. Moreover, screening only indicates if a person is seropositive at a particular point in time. Thus, to be certain of identifying all infected cases, periodic retesting would be required. The substantial costs of investing in a screening program must be measured against similar levels of expenditures needed for research, education, and counseling.

The personal and economic costs engendered by a program of compulsory screening are likely to be disproportionate to the marginal public health benefit. The objective can be achieved in a more effective and less restrictive way through a 
comprehensive, voluntary program of public health education and professional testing and counseling services. Those inclined to seek treatment and behavior control are likely to respond to cost-free, readily available education and services. Such a voluntary program would achieve the same public health advantages as a mandatory program without the significant detriments of the widespread use of compulsion.

\section{Drug Dependent Populations}

Intravenous (IV) drug users are a major risk group for HIV infection in the population. They comprise $21 \%$ of cases of AIDS reported to the CDC. ${ }^{39}$ More important, they are probably the population in which HIV infection is spreading most rapidly. One estimate is that they constitute between $29 \%$ and $32 \%$ of all infected persons. ${ }^{40}$ Further, blacks and Hispanics are disproportionately affected by AIDS particularly among IV drug users. ${ }^{41}$ This illustrates the vulnerability of the population, and often their inability to ensure that their treatment needs are met and privacy rights are safeguarded.

HIV infection among IV drug users is also probably the single most important reason for the spread of infection to non-risk groups, including heterosexuals and children. Some two thirds of all heterosexual cases of AIDS involves past or present IV drug users, their sexual partners, or their children. ${ }^{42}$

Preventing the continued spread of HIV infection within drug dependent populations is one of the major contemporary public health challenges. ${ }^{43}$ But the task is also one of the most daunting. HIV infection among IV drug users is caused primarily by the sharing of contaminated injection equipment (needles and syringes). This behavior is extremely resistant to

39. CDC Surveillance Report, April 1990. For reports of seroprevalence in several major cities, see Mascola, Loren, Iwakoshi, McAllister, et al, HIV Seroprevalence in Intravenous Drug Users: Los Angeles, California 1986, 79 Aм. J. Pub. Health 81 (1989); Chaisson, Bacchetti, Osmond, Brodie, Sande, Moss, Cocaine Use and HIV Infection in Intravenous Drug Users in San Francisco, 261 J. A.M.A. 561 (1989).

40. K. Hopkins \& W.B. JoHNSTON, INCIDENCE OF HIV INFECTION IN THE UNITED STATES (Hudson Institute 1988).

41. Friedman, Sotheran, \& Abdul-Quader, et al, The AIDS Epidemic Among Blacks and Hispanics, 65 Milbank Q. 455 (1987).

42. CDC Surveillance Report, April 1990.

43. See generally Presidential Commission, supra note 1 at 94-104; Schuster, A Federal Agency Perspective on AIDS, 43 Am. Psychologist 846 (1988); Stryker, IV Drug Use and AIDS, 14 J. Health Pol. Pol'y \& L. 719 (1989). 
change. ${ }^{44}$ First, IV drug users are usually physically and mentally dependent on the drug. It is unrealistic to expect them to give up their habits easily. Second, the population tends to be less educated and responsive to traditional modes of public education. IV drug users are an insular minority immersed in their own culture. As a result, modification of their behavior using traditional public health education techniques is a formidable task. There are, however, strong signs that the population is beginning to understand the danger from HIV infection. ${ }^{45}$ Third, obtaining sterile (infection-free) needles is extremely difficult and usually unlawful. ${ }^{46}$ Even if this population consciously chose to inject their drugs more safely, they would have difficulty finding sterile equipment. The legalism and moralism attached to illicit drug use stand as formidable obstacles to controlling the epidemic among drug users.

Given the difficulty of developing a public health strategy to cope with the spread of HIV infection in drug-dependent populations, what is the appropriate course? In countries such as Great Britain, ${ }^{47}$ Australia, ${ }^{48}$ and the Netherlands, ${ }^{49}$ the government has adopted a radical approach. They have a consensus among politicians, law enforcement, and public health officials that the AIDS epidemic is a priority over other competing drug policies. In the United States there is no such clarity, and the tension between interdiction and law enforcement on the one hand and education, treatment and public health on the other has never been resolved.

The United States should follow these European countries in making AIDS the central priority. This is justified on two

44. See Des Jarlais \& Friedman, The Psychotogy of Preventing AIDS Among Intravenous Drug Users: $A$ Social Learning Conceptualization, 43 AM. Psychologist 865 (1988).

45. See Becker \& Joseph, supra note 17; Des Jarlais, Friedman \& Hopkins, Risk Reduction of Acquired Immunodeficiency Syndrome Among Intravenous Drug Users, 103 Ann. InTERn. Med. 755 (1985).

46. Ginzburg, Intravenous Drug Abusers and HIV Infections: A Consequence of their Actions, 14 LAW, Med. \& Health Care 268 (1986).

47. See Anon, Drug Misuse and AIDS Prevention: Policy on the Right Track, 83 BRit. J. Addiction 1237 (1988).

48. See Tsai, Goh, Webeck \& Mullin, Prevention of Human Immunodeficiency Virus Infection Among Intravenous Drug Users in New South Wales, Australia: The Needles and Syringes Distribution Programme Through Retail Pharmacies, 2 AsiaPacific J. of Pub. Health 245 (1988); Wodak \& Penny, A Report on the National Advisory Committee on Acquired Immunodeficiency Syndrome Workshop on the Human Immunodeficiency Virus Infection and Intravenous Drug Abuse, 149 MED. J. OF Aus. 373 (1988).

49. Bunning, Verster $E$ Hartgers Amsterdam's Policy on AIDS and Drugs (Unpublished, Dec. 1987). 
levels. First, the spread of HIV through the IV drug population is fanning the flames of the epidemic and spreading to heterosexual and paediatric populations. Second, developing new strategies and devoting new resources to prevent continued spread of HIV in the IV drug community will probably reduce, not increase, overall drug use. AIDS education, counseling, and treatment can reduce overall demand for drugs: ${ }^{50}$ the fear of HIV can be used as a motivation for behavior change; AIDS education and outreach programs can help gain access to an insular and vulnerable minority; and devoting more resources for treatment expansion can enable more people to get treatment sooner.

The specifics of an overall policy to reduce the spread of HIV among drug dependent people would target the two areas critical for transmission of the virus: use of contaminated injection equipment, including the sharing of equipment, and dependency on drugs.

The transmission of HIV occurs when HIV infected drug users self-administer heroin, cocaine, or other drugs through an injection usually into a vein. The needles and syringes ("works") then may contain small amounts of HIV infected blood. The "works" are then shared with another drug dependent person vithout sterilizing the equipment, risking transmission of the virus. ${ }^{51}$ Sharing of "works" can occur in private or in "shooting galleries" where there is a custom and camaraderie connected with sharing. Thus, one reason for the dangerous practice of sharing needles is purely social. This social aspect can be broken only by getting clear public health information to drug dependent people in their homes, communities, underground cultures such as shooting galleries, and total institutions such as prisons. ${ }^{52}$

Government, then, must be prepared to finance a major education and counseling effort directed toward stopping the sharing of needles and syringes. This requires more than conventional educational messages through television, radio and newspapers. It requires outreach programs utilizing individuals with knowledge about drug activities and access to them; community programs utilizing existing networks and church groups particularly in black and Hispanic neighborhoods; and relaxation of draconian enforcement on users to enable them to come forward for education, counseling, and treatment.

50. See Des Jarlais, supra note 45 .

51. See Ginzburg, supra note 46 , Stryker, supra note 43.

52. T.M. Hammett, AIDS in Correctional Facilities (1986). 
Educational programs designed to encourage safer behavior cannot be successful if drug users do not have access to sterile needles and syringes. Because access to new needles and syringes is highly restricted, drug users often have to use "works" that are supplied by the drug dealer, fellow user or operator of the shooting gallery. These "works," even if they purport to be sold as "new" (with plastic wrapping) are often re-used and unsterilized. Thus, drug users who are encouraged not to share needles in public health education campaigns, may not even realize that they are re-using contaminated needles. The absence of sterile equipment, therefore, poses a public health menace.

There are many reasons why access to sterile injection equipment is highly restricted. The possession of drug paraphernalia is illegal across the country. Most states do allow the purchase of insulin needles and syringes. However, many states in the Northeast, where IV drug use and IV infection are both most prevalent, require a medical prescription for the purchase of hypodermic needles. In these states, the possession and use of needles is strictly limited. In Massachusetts, for example, only specified health care professionals can be in possession of hypodermic syringes, needles, or any instrument adapted for the administration of controlled substances by injection. A physician may write a written prescription for a patient under his or her immediate charge for the administration of controlled substances. A wholesale druggist or surgical supplier must keep careful records of the sale of syringes and needles. Failure to comply with this law is punishable by fine and imprisonment. If a person is charged with illegally possessing hypodermic needles or syringes, he or she has the burden of proving that there is sufficient authority or license to possess them.

The "legitimate medical purposes" doctrine is intended to hold a prescription invalid unless it was prescribed in good faith for a therapeutic purpose. On its face, this would prohibit a physician from prescribing for the purposes of injection of illicit drugs. An argument could be made that a physician can validly prescribe for the purpose of preventing transmission of HIV. This would not, however, seem to comport with the current consensus on what constitutes proper medical practice.

Enforcement of the drug laws add to the public health problem. If a person is found to have drug injection equipment in his or her possession that could be presumptive evidence of commission of an offense. From a public health perspective, this could well discourage a user from carrying 
sterile equipment (perhaps even bleach) to a place where he is going to shoot up.

Perhaps the greatest public health challenge is to devise policies which encourage safer patterns of behavior among drug-dependent people, without appearing to condone use of illicit drugs. It is necessary to take a bold step to help drugdependent people to behave in a safer manner. The prospects for such a bold change in policy look grim in the face of government insistence that drug abuse is a crime that will be dealt with strictly.

One component of a comprehensive public health strategy would be to allow easier access to cost-free sterile equipment. Laws which currently criminalize possession of needles and syringes should be relaxed or repealed. This could be achieved in a number of creative ways. First, possession of needles and syringes should not be regarded as a per se criminal offense. This would allow the drug user to acquire and possess sterile equipment, and not to rely on equipment provided by fellow users, sellers, or those who operate shooting galleries. It would be a cruel irony if a user were to carry sterile equipment to a shooting gallery or a friend's house, only to be arrested for his attempt at safer behavior encouraged by the public health department.

Second, the state could authorize over the counter sales of injection equipment by pharmacists. If greater control of the needle distribution process was thought desirable, the state could extend the "legitimate medical purposes" doctrine to allow doctors to prescribe needles and syringes to reduce the danger of HIV infection. In this way the state could control the conditions under which needles were distributed in different ways. By restricting distribution to persons in treatment, the state would encourage treatment, provide education, and supervise the use of needles.

Another way to ensure the use of clean needles is to educate drug users about the importance of sterilizing their "works." Innovative programs in New York and other cities distribute packets of bleach to drug users and provide instructions on how to sterilize their works. Bleach is very effective in destroying the AIDS virus. Distribution of bleach, moreover, is often more politically palatable than distribution of needles.

The most politically controversial method of ensuring access to new injection equipment is to give them away without cost. Most versions of this kind of policy are called "needleexchange" because drug dependent persons could exchange 
dirty needles for clean ones. In this way, the state keeps control over the number of needles in circulation, but helps encourage greater use of sterile equipment.

There are serious questions about the efficacy and harms of needle exchange programs which need to be addressed. It is argued that such programs encourage use of drugs. There is no evidence that this is so. The availability of clean needles would seldom, if ever, be a sufficient reason to use drugs. Yet, distribution of needles by the state is seen as a powerful symbol. It is argued that the state is giving an ambiguous message, almost condoning the use of drugs. In any case, HIV is a fragile virus. By the time a user turns in his or her needle for a clean one, the virus is probably already dead. On the other side is the positive political symbolism of distribution of needles. This delivers a message that health efforts in the drug community are going forward, and that the user can receive the help of the state even if he or she cannot "say no" to drugs. A political gesture of caring for the health of the drug dependent population could encourage greater cooperation with public health programs.

The importance of clean needle programs can be established on two levels. First, the user who has sterile equipment in his possession has a readily available alternative to dirty needles offered by dealers and other users. This gives the user a choice in protecting his or her health. Second, and most important, needle distribution provides a focal point for intensive education, counseling, and encouragement to seek treatment. When the user comes to receive or exchange his "works," he is accessible to public health efforts that otherwise would not reach this insular population. It can be argued that distribution programs which are too judgmental by offering education and treatment referral won't work as well. The data does not exist to help evaluate these questions. Research evaluation of the efficacy and harms of different distribution models is warranted.

It would be wise to establish needle distribution or exchange programs on a trial basis in designated urban areas. As part of this trial, we could test the needle-sharing patterns of those outside the experimental areas, with several different experimental programs. Experimental programs might test the utility of authorizing only certain facilities, with special controls for distribution of needles and individual and professional accountability.

Whatever method is adopted, some kind of "clean needle" program would be a sound investment in public health. Public 
officials cannot ignore the rapid spread of disease among people who have little meaningful control over their behavior. Such programs have already been established in such countries as the Netherlands, Great Britain, and Sweden. ${ }^{53}$ Some measure of success, at little social cost, has been demonstrated in those countries. These have included a lower transmission rate of HIV, greater participation in treatment, and no increase in drug use. In the U.S., highly limited experimental programs have begun in a few cities including New York and Portland, Oregon.

The final strategy for slowing the spread of HIV in the population of IV drug users is to help decrease their dependence on drugs through treatment. However, there are currently major barriers which impede access to treatment. First, there are severe shortages of treatment places. ${ }^{54}$ This shortage is due to insufficient resources allocated from federal and state governments to treatment for drug dependency. Traditionally, government has perceived law enforcement and interdiction as far more important than treatment, and allocated many times more resources to these efforts.

Another reason for the shortage of treatment slots is that local communities frequently resist placement of treatment centers in their areas, claiming that it will make their neighborhoods more dangerous and less attractive, thereby reducing their property values. In some cases, local governments tacitly support this community resistance by enacting and enforcing strict zoning laws which restrict placement of treatment centers.

A final reason for shortage of treatment slots is too much government regulation which discourages the opening of treatment centers. The federal methadone regulations have very specific requirements as to staff-patient ratios and provision of counseling and services. Complying with these regulations in many cases makes it difficult or prohibitively costly to take on more methadone patients. The original reason for the regulation was sound. Methadone treatment centers were not intended as "watering stations," but active therapeutic environments. However, now with the AIDS epidemic, the need to get users off heroin and to have them use sterile needles under a controlled environment is critical. ${ }^{55}$

53. See supra notes $47-49$ and accompanying text.

54. See Schuster, supra note 43.

55. See Batki, Treatment of Intravenous Drug Users with AIDS: The Role of Methadone Maintenance, 20 J. of Psychoactive Drugs 213 (1988). 
Some localities also prohibit or do not reimburse the use of methadone in hospitals under certain circumstances. ${ }^{56}$ The absurd result is that hospitals must let drug dependent people into the streets knowing they will use heroin and quite probably share needles.

An innovative approach would be the vast expansion of methadone spaces. This could be achieved by relaxing federal regulations; authorizing, even encouraging, hospitals to prescribe methadone; and even allowing general internists and others to prescribe it in their private offices. This approach has now been adopted in Great Britain. The justification is that, until sufficient resources for counseling and education and treatment are allocated, we loosen the dependence on heroin and provide a controlled means for using sterile equipment.

As a result of the shortage, treatment slots have had to be rationed in two ways, both of which have severe public health consequences. The first rationing criterion is ability or willingness to pay. Most drug treatment facilities charge for treatment. Many drug dependent people are unable to afford treatment, even if it is at low cost. Drug users are often unable to hold down regular jobs and have to pay huge costs to support their habit.

The fact that many drug users are unemployed means that they may not have health insurance. Drug users are one of the last groups we would expect to pay for treatment. Even if the drug user is uninsured or can afford treatment, price might be seen as a barrier.

The second rationing criterion is queuing or waiting until a treatment slot becomes available. Drug dependent people have to wait for treatment for several months, even up to a year or more, in many areas of the country. Experience with drug dependent people is that if they are denied a place in treatment, many will not wait until treatment becomes available. During that period they will continue to use drugs and continue with their unsafe needle-sharing behaviors. Ultimately, failure to provide treatment on demand is more costly because of the substantial health care costs to the patient and to others he or she might infect.

American society, particularly in urban areas, is in the midst of two major epidemics - drug use and AIDS. One epidemic feeds the other, with social and financial costs that are staggering. It makes little sense to fail to give individuals the

56. See Hevesi, FDA Extends Methadone Experiment in Harlem, N.Y. Times, Dec. 5, 1988. 
means to reduce their dependence on drugs, which is necessary to meet perhaps the two greatest public health problems in America.

\section{Statutes Designed to Protect Confidentiality}

Individuals infected with HIV are concerned with maintaining the confidentiality of their health status. HIV infection is associated with sexual practice and drug use, universally regarded as sensitive activities. Consequently, the process of case identification per se triggers a concern with confidentiality. The majority of people infected with HIV in the United States are also members of groups subject to persistent prejudice and discrimination. ${ }^{57}$ Unauthorized disclosure of a person's serological status can lead to social opprobrium among family and friends, and to loss of employment, housing and insurance. There are public health pressures to obtain detailed, sensitive information through medical surveillance and contact tracing, such as intrusive observation and disclosure of sexual partners. $^{58}$

Persons at risk of HIV infection, therefore, have strong grounds for desiring personal privacy and confidentiality of medical information. Their cooperation with public health authorities and treatment centers is dependent upon expectations of confidentiality. Efforts to control the spread of AIDS currently rely upon voluntary restraint of behaviors likely to spread HIV. Therefore, the public health objective should be to influence the behavior of those infected with HIV. Trust in and compliance with public health programs depend upon the maintenance of confidentiality.

The Centers for Disease Control early on in the AIDS epidemic embraced a position on confidentiality and the need for state and federal legislation to protect HIV records that was striking. ${ }^{59}$ For those who could not be reassured, for those who believed that no system of confidentiality protections

57. See generally Note, The Constitutional Status of Sexual Orientation: Homosexuality as a Suspect Classification, 98 Harv. L. REv. 1285 (1985): Ginzburg, Intravenous Drug Abusers and HIV Infections: A Consequence of Their Actions, in 14 Law, Med. \& Health Care 268-72 (1986).

58. In California, a referendum that would have declared AIDS a communicable disease and permitted employment restrictions for persons carrying HIV was defeated. California's Proposition 64 Overwhelmingly Rejected by Voters, 1 AIDS PoL'y \& L. 1 (1986).

59. Centers for Disease Control, Recommended Additional Guidelines for HIV Antibody Counseling and Testing in the Prevention of HIV Infection and AIDS (Apr. 30, 1987). 
could protect infected persons from the threat of irrational public policy and private discrimination, health officials responded by providing for testing under conditions of anonymity. ${ }^{60}$

In time, the defense of confidentiality endorsed by the Association of State and Territorial Health Officials, ${ }^{61}$ the American Medical Association, ${ }^{62}$ the Institute of Medicine, the National Academy of Sciences, ${ }^{63}$ and the Presidential Commission on the HIV Epidemic ${ }^{64}$ was to become a centerpiece of the political culture of the AIDS epidemic.

Conservative forces in Congress have resisted the clamor for a federal AIDS confidentiality statute. The problem lies in the line that had to be drawn between confidentiality and public health. In particular, should there be an absolute requirement to maintain confidentiality if there is an unsuspecting sexual or needle sharing partner in immediate danger of contracting HIV. Others would extend that line beyond sexual or needle sharing partners to a broader "right to know" the serological status of infected persons. This "right to know" has been asserted by various groups ranging from health care professionals, "first responders" (e.g., ambulance workers and law enforcers), funeral workers and others who feared occupational exposure to body fluids.

Physicians have been left in limbo by the uncertainties of the law. On the one hand, if they breach confidentiality about their patient's serological status, they face legal liability for breach of confidentiality. On the other hand, if they maintain confidentiality, they risk liability for failure to warn an imperilled third party. This dilemma is evident to physicians in most states.

Remarkably, more than half the states now have special statutes protecting the confidentiality of HIV-related information. ${ }^{65}$ Many of these states have sought to clarify professional

60. See generally Bayer \& Gostin, Legal and Ethical Issues in AIDS, in Current Topics in AIDS (M. Gottlieb, D. Jeffries, D. Mildvan, A. Pinching, T. Quinn, R. Weiss eds.) (vol. 2 in press).

61. Association of State and Territorial Health Officials, Guide to Public Health Practice: AIDS Confidentiality and Anti-Discrimination Principles: Interim Report (1987).

62. American Medical Association, Prevention and Control of Acquired Immunodeficiency Syndrome: An Interim Report, 258 J. A.M.A. 2097 (1987).

63. Institute of Medicine, National Academy of Sciences, Confronting AIDS: Directions for Public Health, Health Care, and Research 125, 129-130 (1986); Update 1988, supra note 1, at 71-74.

64. Presidential Commission, supra note 1.

65. Gostin, supra note 20. 
responsibilities. These states have given physicians a power, not a duty, to warn specified groups at risk for HIV. These groups include spouses, emergency workers, health care professionals, funeral workers, sexual assault victims, lab workers and school administrators.

But these laws create more problems than they solve. A spouse may be at risk for HIV, but this leaves out equally vulnerable sexual and needle sharing partners who cannot be warned. At the same time, the statutes yield to wider claims for a "right to know." This is highly problematic because it gives a power to breach confidentiality in order to warn a person whose risk is very low. The risk assumed by non-sexual or needle sharing partners is remote and hardly justifies an exception to the important principle of confidentiality. This slippery slope is exactly what has worried some public health officials and risk group members who have called for the absolute inviolability of confidentiality.

A rational line needs to be drawn between confidentiality and the right to know. Strong statutes which safeguard confidentiality on a federal and state level would be just and advantageous to the public health. A power, but not a duty, to breach that confidence should arise only if there is an identifiable third party at serious and immediate risk of transmission by a sexual or needle-sharing partner.

\section{Anti-Discrimination Statutes}

Times of epidemic are also times of social tension. Fears exacerbate already extant divisions revealing and deepening social fault lines. ${ }^{66}$ Discrimination against persons with HIV infection has become a worldwide phenomenon. ${ }^{67}$ The AIDS virus has divided nations, ethnic, cultural and sexual groups, and individuals. ${ }^{68}$ The potential for greater division is ever present.

HIV infection has been used as a rationale to exclude children and adults from education, jobs, housing and insurance. America has read all too frequently about children with HIV being turned away from schools, of employees dismissed from their jobs and losing their life or health insurance, and of AIDS patients not receiving appropriate treatment or of being forced

66. See Gostin, The AIDS Litigation Project Part I: The Social Impact of $A I D S, 263$ J. A.M.A. 1961 (1990).

67. Bayer \& Gostin, supra note 60.

68. R. Sabatier, Blaming Others: Prejudice, Race and Worldwide AIDS (1988). 
by circumstance to stay in hospitals because they have no home to go to. Hundreds of cases have now been brought by persons with HIV claiming discrimination before human rights commissions and courts. ${ }^{69}$

Discrimination based upon an infectious condition can be as inequitable as discrimination based on other morally irrelevant grounds such as race, gender or handicap. The U.S. Supreme Court has recognized that: "society's accumulated myths and fears about disability and disease are just as handicapping as are the physical limitations that flow from actual impairment. Few aspects of handicap give rise to the same level of public fear and misapprehension as contagiousness."70

But there is a critical difference between discrimination based upon race or gender and discrimination based upon disease status. An infection is potentially transmissible and can affect a person's abilities to perform certain tasks. A decision to exclude an HIV-infected person from certain activities because of a real risk of transmission or performance criteria would be understandable and would not breach anti-discrimination principles. But, denying such persons rights, benefits or privileges where health risks are only theoretical or very low and when performance is adequate is morally unacceptable. Since the risk of transmission of HIV in most settings is remote, ${ }^{71}$ and since persons with HIV infection may function normally when not experiencing serious symptoms, there are no morally acceptable grounds for discrimination.

Irrational fears of AIDS are typically at the root of HIVrelated discrimination. Public opinion surveys reveal that a consistent minority harbor anxieties about and antipathies toward those with HIV infection. On a wide variety of questions some one fourth of the public believe people with HIV should be excluded from schools, workplaces and other public settings. Such findings have been replicated in many regions of the world. ${ }^{72}$ Fueling both anxieties and antipathies is often a visceral hostility to those groups linked to AIDS - gay men, drug users and prostitutes.

Not only is discrimination against the HIV-infected morally wrong, it can also be counterproductive from a public

69. Gostin, The AIDS Litigation Project, Part II: Discrimination, $263 \mathrm{~J}$. A.M.A. 2086 (1990).

70. School Bd. v. Arline, 480 U.S. 273 (1987).

71. See Friedland \& Klein, supra note 13.

72. See supra notes 8-9 and accompanying text. 
health perspective. The World Health Organization, ${ }^{73}$ the Institute of Medicine, ${ }^{74}$ the American Medical Association, ${ }^{75}$ and the Presidential Commission on the HIV Epidemic ${ }^{76}$ have all termed HIV-based discrimination unjustifiable and inimical to the goal of public health.

Fears of a breach of confidentiality and subsequent discrimination discourage individuals from cooperating with vital public health programs and treatment for sexually transimitted diseases and drug dependency. These fears also mobilize opposition to routine voluntary testing and counseling among people with high risk behaviors. Such resistance to testing might well melt away if individuals believed they were strongly protected by the law.

Because of the unethical character and detriment to public health of discrimination, public health and advocacy groups alike have pressed for legislative and judicial remedies. First, there has been an effort to use extant statutory protections designed to protect handicapped individuals. The federal Rehabilitation Act of 1973 , section 504, prohibits discrimination against "otherwise qualified" handicapped people. There is little doubt among legal scholars that the 1973 Act does apply to AIDS, and probably to HIV infection. ${ }^{77}$ An amendment to the Rehabilitation Act states that a person with a contagious disease or infection is protected if he or she does not "constitute a direct threat to health or safety" and is able "to perform the duties of the job."78 The courts, moreover, have consistently held that HIV-related diseases, including asymptomatic HIV infection, are covered under the $1973 \mathrm{Act}^{79}$ The major limitation of the 1973 Act is that it is applicable only to programs receiving federal financial assistance and does not

73. World Health Organization, Global Programme on AIDS, Progress Report No. 3, WHO/GPA/GEN/88.1 (1988).

74. Update 1988 , supra note 1 .

75. American Medical Association, supra note 62.

76. Presidential Commission, supra note 1.

77. See, e.g., American Bar Association AIDS Coordinating Committee, AIDS: The Legal Issues (1988); Memorandum from D.W. Kmiec of the U.S. Department of Justice to the Counsel to the President on the Application of Section 504 of the Rehabilitation Act to HIV-Infected Individuals (Sept. 27, 1988).

78. Civil Rights Restoration Act of 1987, Pub. L. No. 100-259, 557 (Mar. 22, 1988).

79. See, e.g. , Chalk v. Orange County Dept. of Educ., 832 F.2d 1158 (9th Cir. 1987); Doe v. Centinela Hospital, 57 U.S.L.W. 2034 (C.D. Cal. June 30, 1988) (No. CV 87-2514); Ray v. School Dist., 666 F. Supp. 1524 (M.D. Fla. 1987). 
significantly extend into the private sector. The Fair Housing Amendments Act of 1988 extends non-discrimination protection for people with disabilities to the private sector, so that private landlords and owners cannot discriminate against persons with HIV. The Americans with Disabilities Act will be introduced in the 101 st Congress to include a wider number of areas including employment, accommodations, and stores.

The fifty states and the District of Columbia have handicap statutes similar to the federal Rehabilitation Act. In all jurisdictions except five, handicap statutes prohibit discrimination against employees in both private and public sectors. In 34 states, the courts, ${ }^{80}$ human rights commissions or attorneys general have formally or informally declared that handicap laws apply to AIDS or HIV infection. ${ }^{81}$

But to those who have doubted the adequacy of such statutes and for whom the explicit defense of the rights of those with HIV infection is perceived as socially and politically crucial special AIDS related enactments have had a special allure. Thus, many states and municipalities have enacted AIDS-specific statutes or ordinances that target specific areas such as employment, housing, or insurance. Local ordinances, such as in San Francisco and Los Angeles, are more comprehensive in prohibiting discrimination in business establishments, public accommodations, educational institutions, and municipal facilities or services. ${ }^{82}$

But political forces at the national level in the United States would not, in 1988, permit the inclusion of antidiscrimination provisions in the first comprehensive congressional legislative statement on the epidemic. In the face of a national challenge, they had forcefully argued, it was a terrible error to rely on the vagaries of state law. At the time of writing, the Americans with Disabilities Act was on the verge of passing the U.S. Congress. The ADA would be the most sweeping civil rights measure sine the Civil Rights Act of 1964 with respect to handicapped people. For the first time, it will comprehensively extend antidiscrimination protection to people with disabilities, including HIV infection, to the purely private sector.

There can be little doubt about the threat of discrimination. Nor can there be any question about the need for

80. See, e.g., Shuttleworth v. Broward County, 639 F. Supp. 654 (S.D. Fla. 1986); Cronan v. New Eng. Tel. Co., No. 80332 (Mass. Aug. 15, 1986).

81. National Gay Rights Advocates AIDS and Handicap Discrimination: A Survey of the 50 States and the District of Columbia (1986) (updated as of Jan. 1988 by the ADA at the Annual meeting of the APHA, Nov. 14, 1988).

82. See Gostin, supra note 20. 
national protective legislation which goes beyond the public sector limitations of current statutory provisions. The unwillingness to provide such protections presents a moral and political failure. What is critical is that as a matter of public policy those vulnerable because of HIV infection must be protected. The most elemental notions of human dignity as well as the public health require no less.

\section{Conclusion}

Persons with AIDS are gripped by a devastating disease process. In addition to coping physically and psychologically with the disease, they may have had to face rejection, alienation, discrimination, and financial ruination. The challenges ahead will test society - its fairness, compassion, and expertise in law, medicine, and public health. We are at a pivotal moment in the epidemic. Federal and state governments must act now to devise the policies and allocate the resources necessary to combat AIDS. Failure to devise and implement strong policies will cost the country its most vital resource - the health and well-being of a predominantly young and vigorous population. 